\title{
REVIEWS
}

\author{
RAFAEL BAENA ESCUDERO, BELÉN GARCÍA MARTÍNEZ, INMACULADA \\ GUERRERO AMADOR, FILIP HARTVICH, BRIGITTE LEICHT, LARA MARCHIOL \\ ET AL ${ }^{1}$
}

\section{FLOODS 2002 IN PRAGUE - REFLECTIONS, LESSONS AND IDEAS}

\begin{abstract}
R. Baena, B. García, I. Guerrero, F. Hartvich, B. Leicht, L. M a r chiol et al.: Floods 2002 in Prague - reflections, lessons and ideas. - Geografie - Sborník ČGS, 109, 2, pp. 170-180 (2004). - This contribution deals with the consequences of floods, which affected the capital of CR, Prague, in august 2002. The members of working group have seen the situation one year after the event. The article is divided into three parts, each dealing with specific area of problems. First part concerns the measures that should be taken before the flood event occurs, including long-term flood protection strategy. In the second part we discuss the succession of steps to be performed in order to minimize the endangerment of public and the damages during the flood period. Last section suggests solutions and lessons that might be taken from the 2002 flood event's course and its consequences in Prague.
\end{abstract}

KEY WORDS: 2002 floods - Prague - Vltava - flood consequences - Erasmus programme.

\section{Introduction}

Under the Intensive Programme (29716-IC-1-2001-1-ERASMUS IP-5) Water management in transition countries, on the subject "Water resourcestheir management and protection", the Work Group "Flood and flood protection" analysed the floods in August 2002, in the Vltava River, on the stretch through the city of Prague.

The workshop activities and the scientific learning process can be divided into three stages:

1. Preparation phase: To prepare themselves for the stationary seminar, all the working group participants received an introductory essay which contained the necessary basics on the issue of "Flood and Flood Protection" in the Czech Republic. The emphasis was laid on the August 2002 flood catastrophe.

2. On-site-learning phase: During the stationary seminar in Prague the following activities were arranged to improve the group-knowledge about the causes and effects of the August 2002 flood:

a) introductory expert lectures

b) excursions to different sites in Prague which were heavily afflicted by the flood (the suburbs of Karlín and Troja with the Zoo, the Metro system) and to the main flood forecasting office (Czech Hydrometeorological Institute)

c) expert interviews with geographers, hydrologists and meteorologists

1 Laura Giacomini, Andrea Guaran, Alexandra Králová, Andreas Licht, Hannah Neu, Luca Pezzullo, Veronika Weingerová 
3. Post-processing phase: Discussion of facts within the group, processing of information and presentation of results and compilation of the results in a working-group report.

During the post-processing phase it became clear to the group that the issues dealt with and discussed should be related to three levels of subject:

I. Before flood: studies of history, geomorphology, land ordination, etc. What do we know about river and its surroundings?

II. During flood: work plans, evacuation and coordination. During August 2002's catastrophe - what was the situation and what were the actions taken? Was everything possible done?

III. After flood: restoration and cleaning of the city and damage evaluation, embedding the gained knowledge in city planning. What lessons should be learned from the flood?

We decided to follow the same structure when composing this article.

\section{The 2002 flood in Prague}

\section{1 Before flood}

There are two key assumptions for the ordination of land located on river banks: firstly, the fact that floods are not disasters but rather natural phenomena responding to extreme although frequent processes in the function of rivers, hence the existence of flood plains and their associated morphology (Ward 1978; Mateu 1990; Díaz, Baena 1999). It is, therefore, the human intervention involved in locating towns or cities on river banks, with their high population and concentration of activities, which prompts and increases the risk (Parker et al. 1982; Baena, García 1995). Secondly, the fact that a prompted risk such as this should be dealt with as a problem of interaction between society and the environment (Burton et al. 1978; Guerrero, Baena 1996).

The obvious solution is to study the geometry of the potentially floodable areas from a historical and hydrogeomorphological viewpoint. This is grounded on the conceptual bases and methods used in fluvial geomorphology (Pardé 1955; Tricart 1961, Thorner 1980) applied both to ordination and to the restoration of rivers (Guerrero, Baena 2002).

First task is to notice the historical floods and their parameters and then we will define the morphohydrological units (Baena, Guerrero 2002; Guerrero, Baena 2002), which allows greater understanding and explanation of the distribution and extent attained by the floods in the stretch of the Vltava River running through the city of Prague.

\section{1.1 Vltava and its flood history}

The historic series of exceptional river flows in Prague, since 1827, shows the general trend noted in European rivers towards a reduction in exceptional flows over the last two centuries (Petts et al. 1989), this only being interrupted by several isolated events during the second half of the 19th century $\left(4,500 \mathrm{~m}^{3} \cdot \mathrm{s}^{-1}\right.$ in 1845 , and $4,000 \mathrm{~m}^{3} \cdot \mathrm{s}^{-1}$ in 1862 and 1890) and one (!) in the mid $20^{\text {th }}$ century $\left(3,300 \mathrm{~m}^{3} \cdot \mathrm{s}^{-1}\right.$ in 1940$)$.

The extent of rainfalls recorded in the Czech Republic for August 2002 represents an exceptional phenomenon due to the regional coverage of the 
area affected (tens of thousands $\mathrm{km}^{2}$ ) and the persistence (from $6^{\text {th }}$ to $15^{\text {th }}$ August 2002) and the intensity of the same throughout Central Europe. The following discharge amounted to $5,160 \mathrm{~m}^{3} . \mathrm{s}^{-1}$.

\section{1. 2 Morphohydrological units}

Geomorphologically, the stretch of river flowing through Prague itself responds to the meandriform model, winding gently with a wide, medium gradient flow and a mixed load (gravels and sands), running through a reduced flood plain as this is hemmed in by hillsides. These characteristics limit the possibilities of lamination of the peak-flows, generating alternation in the convergence and divergence of the flood flows, depending on if straight stretches are followed by bends or if natural or artificial obstacles interfere with current circulation. Between Vyšehrad and Sedlec are concerned, three morphohydrological units have been differentiated between, from South to North (see Fig. 1):

Vyšehrad-Letenské sady unit: Here the flow is limited by high embankment walls, with the exception of areas of ancient mills and laterally positioned isles (Kampa, Žofín, etc.) This led to an imbalance in the action of the river, which is more active on the lower left bank (Kampa, Vojanovy sady), unprotected by mobile barriers (due to historic city protectionists), while on Old Town side the barriers proved highly efficient. In this unit, many people would have to be evacuated in the case of barriers overflow. This zone

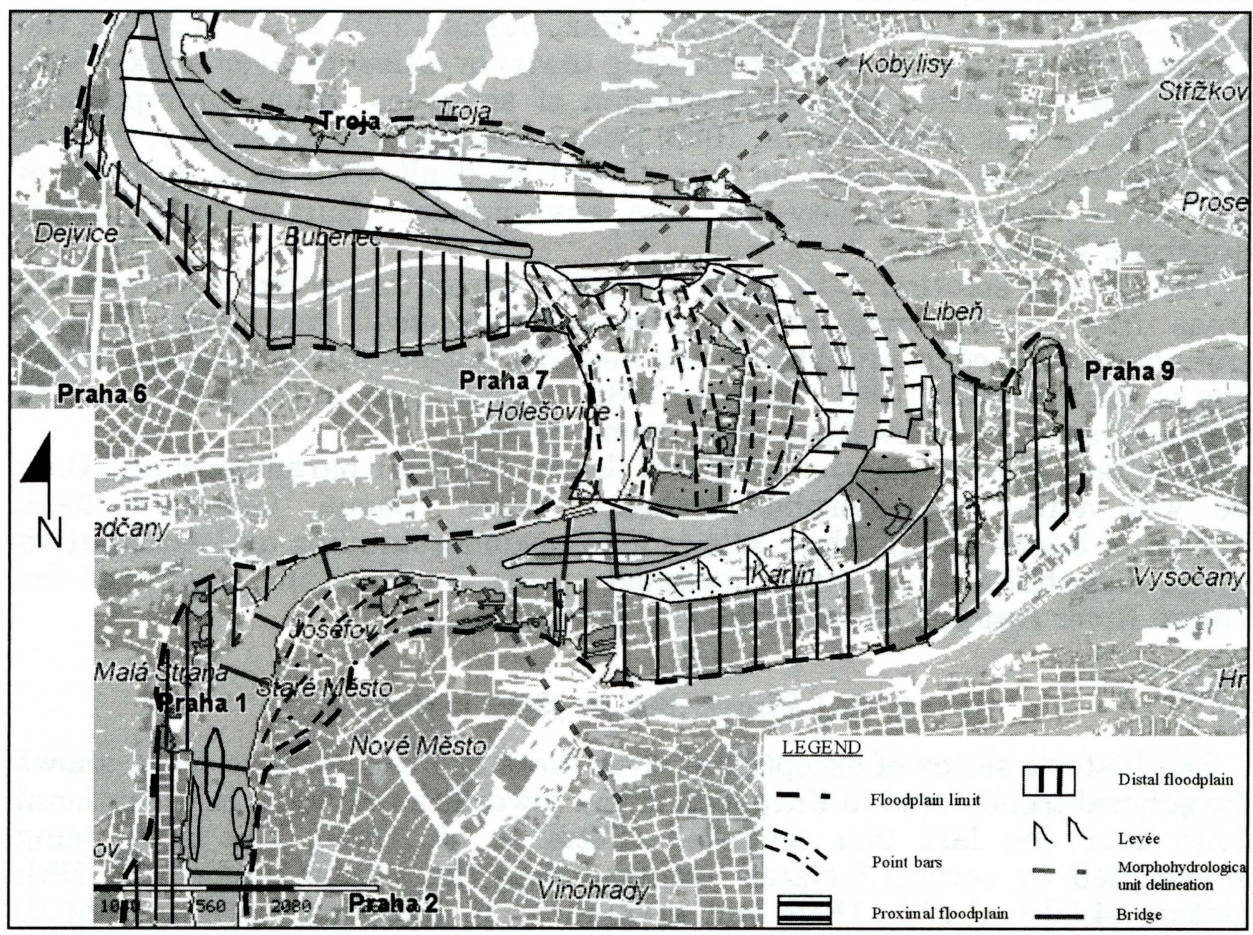

Fig. 1 - Morphology of Vltava floodplain in Prague; a (dotted line) - floodplain limit, b (dash-and-dot line) - point bars, c (horizontal hatch) - proximal floodplain, d (vertical hatch) - distal floodplain, $\mathrm{e}$ - levée, $\mathrm{f}$ - morphohydrological unit delineation, $\mathrm{g}$ - bridge. 
corresponds to the historic sector of the city, of high historical value and includes famous Charles Bridge, an important axis around which tourism is articulated.

Karlin-Holešovice unit: Including the great Holešovice meander, geomorphologically it represented the essential sector for lamination of peakflows of the Vltava River in this area after the narrowing stretch found in the previous unit. Within this unit, the divergence of flows occurs, with important depositional effects of point bars in Holešovice, and vertical in the concave bench of Karlín, either in the form of sands and limes (overbank deposits) in the levee that nowadays represents the old isle of Rohansky, or in the form of clays (channel-fill deposits) in the abandoned meander area of Karlín. This unit has undergone a greater number of changes during the Holocene, both of a natural character (lateral movements of meander with moments of expansion and the formation of point bars on the right bank, such as neck cut off of the same with the abandonment of the river course), and of an anthropic origin linked to the development of Liben, Holešovice and Karlín.

Troja-Bubeneč unit: Integrating the old sedimentary decantation stretch par excellence, due to the pool of overflows before concentrating once again after Bubeneč. Nowadays, because of the contemporary change that occurred in the previous unit, this represents the only area available for flood inundation. Hence, its function as a proximal flood plain and, therefore, subject to a progressive increase in the effects of flooding. The Pelc-Tyrolka area, on the Troja bank towards which the most intense flows from the Liben and Maniny areas run, is noted for its vulnerability.

\section{2 During the flood}

\section{2. 1 Initial conditions}

The August 2002 flood in the Czech Republic was caused by two waves of intensive precipitation. The first wave hit the Czech Republic from August 6 th to 8th. The rain belt connected to the frontal system stayed stable over the southern part of Bohemia for more than one day and released extensive rainfalls leading to a complete saturation of the Vltava river basin. Only two and half days later, on August $11^{\text {th }}$, the next depression, accompanied by heavy rainfalls, reached the Czech Republic and moved only slowly through southwest Bohemia to Moravia. At this point, the river basins were still saturated. Though Vltava Cascade was able to absorb the discharge of the first precipitation wave, its retention capacity was overburdened with the second wave. A few kilometres upstream from Prague, the Vltava meets with the Berounka river, whose recurrence period of maximum discharges at that time exceeded 500 years. Additionally, the peaks of the two rivers' flood waves met at the same time. It was the combination of all those coincidences, which was at the end able to cause one of the biggest catastrophes the city of Prague has experienced.

\section{2. 2. Forecast and warning system}

In case of a flood, there are flood commissions of municipalities, of river basins and the Central Flood Commission of the Czech Republic who are responsible for the organisation and management of flood control and flood protection (Šolc 2002). 
The flood forecast and warning service is one task of the Czech Hydrometeorological Institute (PVS CHMI). The central forecasting office $(\mathrm{CFO} / \mathrm{CPP})$ is located in Prague Komořany, furthermore there are regional forecasting offices (RFO/RPP) located in the former regional capitals. The forecast and warning system is based on complex input data like radar data from the national and Central European radar network, satellite data from Meteosat and the US polar satellites and from ALADIN, the regional weather modelling system.

The CHMI cooperates closely with the state-run river basin authorities (Povodí). In case of a flood, the warnings and informative reports of the CHMI concerning the current situation are distributed through the operation centre (OPIS) of the Fire Rescue Service to the adequate addressees, i.e. to flood control commissions, bodies of public administration like the. Ministries of Environment, Agriculture and Interior, all Povodí companies' control centres and to the Czech Television that informs the citizens. Information can also be found on the institute's website.

During August 2002 flood, the CHMI operated day and night and continuously sent alerts, warnings and informative reports about flood development and forecasts to the above mentioned institutions which were responsible for crisis management and public information. Unfortunately, there were also considerable problems that had to be faced: the unexpected extremity of the flood, the variety of influencing parameters (exact dispersion of the forecasted precipitation, information about the runoff-rates from reservoirs, etc.) and uncertainties (missing data due to flooded or destroyed gauging stations), as well as time stress and the lack of scientific experience with such extreme situations, finally defined the limits of such a well organised forecasting system.

\section{2. 3 The situation in Prague during the flood of August 2002}

In the following text some examples are given to present a picture of what was the situation like in Prague during the flood.

Karlin: Karlín is Prague's first suburb, which was erected according to a development plan in the year 1816. It is located immediately outside the original city walls built. It consists mainly of blocks of flats with inner courtyards. In the 1890s Karlín changed to a typical quarter of the working class when textile manufactures and later on factory floors of heavy industry were settled (Schneibergová 2003). The whole quarter was evacuated in August 2002. The damage of the flood can still be seen by means of collapsed houses (Fig. 2). Only in September 2003 the tram lines started operating again. Some houses are still uninhabited and the missing plaster of the walls shows the water level of the Vltava River during the flood. It has to be highlighted that during flood, the Karlin area did not receive the same protection as for example the old city district even though it is more densely populated.

"River City Prague": The "River City Prague" site is located on 6 hectares at the tip of a 66 hectare disused railway yard, parallel to the Vltava River along Rohanské embankment and opposite of Stvanice Island. It forms an extension of Karlín, at a distance of only a few minutes walk from the city centre. The "River-City-Prague"-project was designed as a high standard business district, which should serve to revitalise the area. The aim is to strengthen the integration of Karlín into the existing city structure (Rivercity 


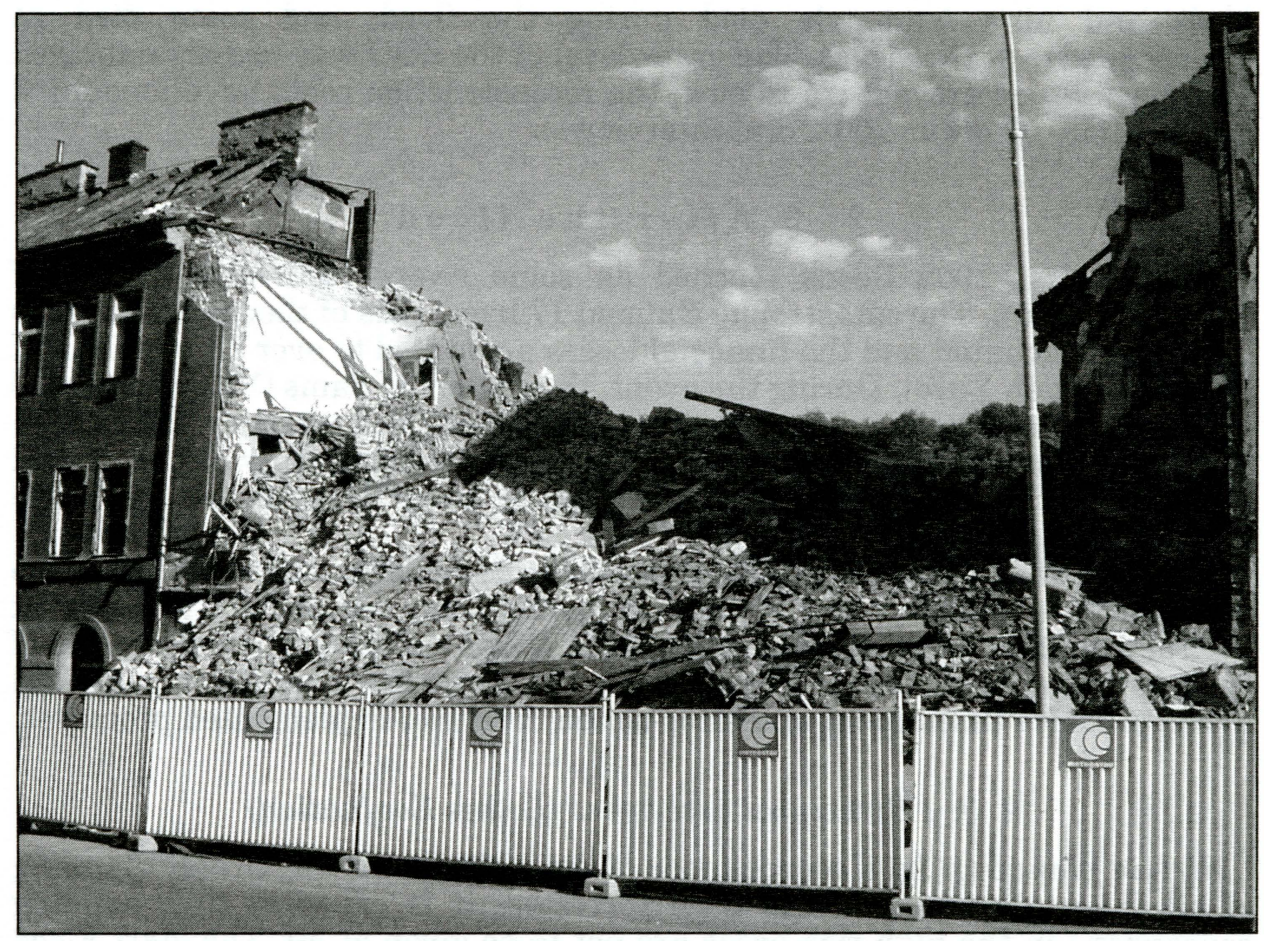

Fig. 2 - Collapsed building in Karlín (summer 2002)

Prague 2003) and to build up an additional. In August 2002 the construction work was at a more or less initial state. As the complete area was seriously affected by the flood (see fig. 2), it was feared that investments could be withdrawn.

The Metro: The damage in the whole ČR during August 2002's flood amounted to 73 billion CZK (> 2,5 billion ), $10 \%$ of which was caused in the Metro system (damages or loss of technical equipment, electricity system). On average, the Metro transports more than 1 million people per day. Serious actions (i. e. closing of the stations) were not taken until August $13^{\text {th }}-$ at the very peak of the flood. At that point many people still had to be evacuated from the metro stations.

This can be considered as a key problem of decision-making:

- Who should take the responsibility for the decision to close the Metro system (administration, municipal transport services)?

- What if at the end it would not have been necessary - who would have to justify the financial losses and costs, which are connected with a closure, and evacuation measures?

An early closing of the Metro would have saved a lot of money!

Troja and the Prague Zoo: Troja is one of the northern outskirts of Prague and Prague $\mathrm{ZOO}$ is located here. The situation in the ZOO was especially dramatic: They were prepared for a 20 to 50 year flood and it was not before the night of August $12^{\text {th }}$ that the fact that it is going to be worse was displayed. If they would have been correctly informed a day earlier, more animals could have been saved. In total 1.000 animals were evacuated (750 birds, 100 mammals and 150 critters) within only three days. However, 80 
birds and nine mammals died during the flood; and some died as a consequence of the stress. The lower level of the $\mathrm{ZOO}$ was heavily damaged and partially destroyed. Up to now, the reconstruction costs have amounted to 2 million (Lothar 2002, oral interviews).

\section{3 After the flood}

The August 2002 floods reached on some rivers recurrence period of 500-1 000 years. The catastrophe claimed 17 lives, tens of thousands citizens had to be evacuated and the financial losses amounted to over 73 billion CZK (over 2,5 billion Euro). During the event, the system of dams (Vltava cascade) was of little use for the mitigation of over 500 years flood category. It has been calculated that, even if the reservoirs had more storage empty at the arrival of the flood, these would not have been able to lower the peakflow discharge of more than the $8 \%$.

The extremity of the flood 2002 suggests some remarks and ideas about the losses, their evaluation and protection against their repeating. The complex interaction among economical, insurancial, social and geographical aspects of such catastrophical events brings forth the need for a multicomponential model of losses assessment and after-action review of implemented processes.

\section{3. 1 Structural assesment (Losses Evaluation)}

Urban planning: As a consequence of the 2002 Flood, the Urban Planning of all the high-risk zone has been corrected: it is expected that building concessions in the high-risk areas are not to be given at all. The 2002 Flood could represent the right occasion to start a project based on the rigorous control of the widespread building along the Vltava river.

Economical: industrial/structural: The Restructure Planning of the afflicted area has to be taken into consideration: not only architectural aspects, but also social and economic geography plays an important role in this project. To summarize the best solution for the situation in Karlín would be an agreement between Czech authorities and international investors: while local administrators allow finishing of the River City Prague along the Vltava river - in a high-risk zone - the foreign investors should realize adequate flood protection measures, thus protecting the old part of Karlín as well. Gradually some of the industrial activities buildings could be removed from Karlín to a low-risk zone.

Economical: financial/insurancial: As a result of the significant losses by the 2002 flood the insurance companies have redefined the risk zones. On one hand the insurance ban on areas up of Q20 agreement could help, but on the other hand it is not clear if there is a real collaboration between private insurance companies and public local institutions. In this case new studies could only help companies to plan their insurance policy in a better way, reducing their payments.

\section{3. 2 Non-structural assessments (Processes evaluation)}

Emergency planning troubles: The emergency planning was more efficient and accurate than in the case of the 1997 flood: then the emergency decisionmakers' inexperience, people's confusion and the incorrect (panic-provoking) media information caused many mismanagements and troubles. After the 


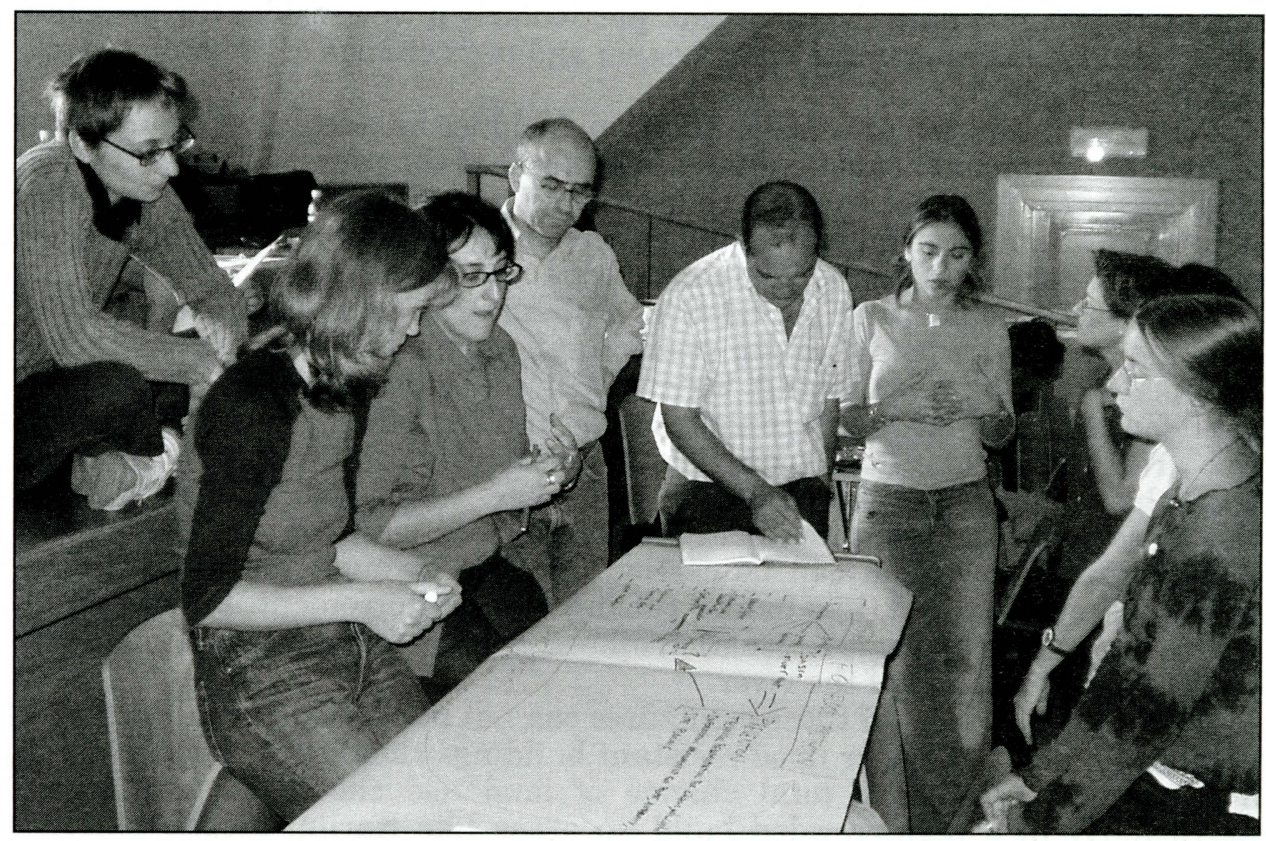

Fig. 3 - Working group „Floods“ at work

2002 flood experience many municipalities developed a Flood Management Plan; the emergency planning process is therefore greatly enhanced, but there is always space for improvement.

Interaction among authorities: In future, it will be necessary to enhance the real-time operational coordination among Municipalities, River Basin Authorities and Scientific Agencies, although the cooperation seems to be much better than in the 1997, when even basic communication appeared to cause problems.

Community involvement: The Community Resilience factor - a very important vulnerability measure - was improved by 1997 flood. While in the 1997 hardly anybody knew the simplest disaster behaviour rules, in the 2002 the general level of information and knowledge was much higher.

An involvement of people in the risk management can improve the CR factor. The following conditions help to reach the target:

- clear risk prevention campaign

- involvement of communities in the land-use policy

- improving the communication among communities, important companies and private insurance firms in the high-risk zones

- defining of the emergency priorities and their announcing to the citizens.

\section{Conclusion}

The Prague city area flooded during the summer of 2002 once again underlines just how the presence of man and his activities on the floodable banks of a river turns a natural phenomenon into disaster perceived as exceptional. The solution involves admitting that river level situations of this 
nature $\left(5160 \mathrm{~m}^{3} / \mathrm{s}\right.$.) may be recurrent, particularly if we consider the principle of instability, changes in the river system and even change of its main control factor - climate.

For this reason, the preventive solution, includes an adequate organization of river environment. This involves assuming that the preservation of a given river sector (in this case the stretch between Vyšehrad and Letenské sady) for its historical and patrimonial value, means to allow the water to overflow out of the channel downstream, i.e. under Letná and Josefov.

Therefore, this is either provided by a planning of exceptional water flows over the Holešovice point bars by restricting building and clearing part of the floodplain, or the overflowing waters will continue to return to the old abandoned course on the floodplain of Karlín. The other areas identified in this article as a close flood plain should exclusively contain uses compatible with their high frequency floodable character, which will doubtless avoid these problems occurring in other areas of the river's course.

Structural prevention can be carried out also through the improving of works already realized, like banks' raising and reinforcement. Furthermore, where the geomorphological situation allows, polders and dry ponds should be built along the course of the river.

It is clear that most of these structures can not be carried out in Prague: it is unavoidable that either flood-resistant buildings should only be allowed in endangered zones, or a total change of land use should be introduced, particularly in a high-crowded build up areas like Karlín. Mobile barriers represent the best additional solution on high embankments, having limited environmental and visual impact.

From the non-structural activities, it is always necessary to improve and renovate flood warnings and evacuation plans; this is possible using the sound network among institutions, as suggested above. Creating clear and strict laws in the urban planning is one of the most important things to do to prevent the worst consequences of natural catastrophes. Using the GIS - Geographic Information System - may help to determine the areas in danger and consequently classify the high-, middle- and low-risk zone.

\section{1 Was everything possible done correctly?}

From a distant perspective, it is difficult to judge whether the actions taken during the flood were sufficient and if decisions were made the right way or not.

First of all, it seemed as if the work of the CHMI and the organisation of the flood forecasting system are excellent, but also limited when it comes to the point where science and technology face situations of such a particularity and extremity as during August 2002's flood.

As far as the flood protection system is concerned, in a first step, the incomplete system of the mobile barriers and secondly the question of prioritising could be discussed. Was it a good decision to give the old citydistrict top priority instead of protecting first area, which are more densely populated (like Karlín)?

Regarding at the situation in the Metro system, it is hard to understand why actions were taken so late. One could assume that this was (economically) calculated risk without any sense of responsibility. Let's highlight the paradox of the final results: It was the late closing of the Metro system that was responsible for the main share of the material losses in Prague. 
It has to be awaited what lessons have been learned from the experience of August 2002 flood concerning the civil protection. Is there an evaluation system, which reveals deficiencies, and will those be smoothed out?

\section{References:}

BAENA, R, GARCIA, B (1995): Repercusiones de la intervención antrópica contemporánea sobre la llanura aluvial del río Guadalquivir aguas arriba de Sevilla. In: "Actas del XIV Congreso Nacional de Geografía”. AGE-Universidad de Salamanca. Salamanca, pp. 5264.

BAENA, R, GUERRERO, I (2002): Morphohydrological elements and unities from Entremuros (National Park of Donana) to restore its original dynamics.. In: "Integrated assessment and management of the ecosystems affacted by the Aznalcollar mining spill (SW, Spain)".IOC/ICAM/UNESCO Technical report, Paris, pp 115-120.

BURTON, I et al. (1978): The Environment as hazard. New York, Oxford University Press.

DIAZ, F, BAENA, R (1999): La restauración geomorfológica del río Guadiamar. En: "International Seminar Corredores ecológicos y restauración de ríos". Sevilla, Junta de Andalucía, $78 \mathrm{pp}$.

GARCIA, B, BAENA, R (1997): Cambios históricos en la hidrología del Guadalquivir y su repercusión en el meandro de Tocina (Sevilla). In: "Cuaternario Ibérico", Asociación Espańola para el Estudio del Cuaternario (AEQUA), Sevilla. pp. 368-371.

GIL OLCINA,A, MORALES, A (1989): Avenidas fluviales e inundaciones en la cuenca del Mediterráneo. Instituto Universitario de Geografía, Alicante, $586 \mathrm{pp}$.

GUERRERO, I, BAENA, R (1998): La inundación del Guadalquivir en diciembre de 1996 (sector Alcolea del Río-Cantillana, Sevilla. In: "Investigaciones recientes de la Geomorfología espańola", Geoforma Ediciones, pp 25-37

GUERRERO, I, BAENA, R (2002): Geomorfologia Fluvial y restauración ambiental: el ejemplo del río Guadiamar en la zona de Entremuros (Parque Natural de Dońana). In: "Estudios recientes (2000-2002) en Geomorfología, Patrimonio, Montańa y dinámica Territorial”. SEG-Universidad de Valladolid. Valladolid, pp. 79-90.

LOTHAR, M. (2002): Prager ZOO erlebte bei Jahrhunderthochwasser seine Apokalypse. http://www.radio.cz/.

de/artikel/31364

MATEU, J (1990): Avenidas y riesgos de inundación en los sistemas fluviales mediterráneos de la Península Ibérica. Rev. Asociación de Geógrafos Espańoles, No. 10, 2Ṣ época. Madrid, $103 \mathrm{pp}$.

PARDE, M (1955): Sur le méchanisme des transports solidez efectües par les rivičres et sur l"alteration consecutive des lits fluviaux. Revue Géographie Alpine, No. 5-40. Lyon, pp 289-315.

PARKER, D. J, PENNING-ROWSELL, E. C. (1982): Flood risk in the Urban Environment. Geography and the Urban Environment, V, John Wiley and Son, Chichester, pp 201-239.

RIVERCITY PRAGUE (2003): http://www.kpf.com/Projects/rivercityprague.htm.

SCHNEIBERGOVÁ, M.(2003): Debatte über Karlín. http://www.radio.cz/de/artikel/41771.

SCHUMM, S.A (1977): The fluvial system. John Wiley and Sons, London, 338 pp.

ŠOLC, J. (2002): 2002 Floods - Use of Information Technology and Territorial Data. Prague.

THORNES (1980): Rivers channels. McMillan, London, 46 pp.

TRICART, J. (1961): Los tipos de lechos fluviales. Revista Geográfica, Vol. II. No.ṣ 5-6, pp 719.

WARD, R. (1978): Floods. A geographical perspective, London, MacMilan, 224 pp.

\section{Shrnutí}

\section{POVODNĚ 2002 V PRAZE - NÁPADY, REFLEXE A POUČENÍ}

V rámci náplně Intenzivního Programu Erasmus, konaného pod názvem „Management vodních zdrojů v zemích bývalého východního bloku" na půdě Univerzity Karlovy v Praze ve dnech 22.-31.8. 2003, řešily jednotlivé pracovní skupiny zadaná témata, přičemž na kon- 
ci semináře každá skupina prezentovala své výsledky jednak formou přednášky s diskusí, jednak shrnujícím článkem. Tento článek je jedním z výsledných výstupů pracovní skupiny "Povodně a protipovodňová ochrana".

Náplní článku je popis, analýza a závěrem i několik postřehů a doporučení, týkajících se průběhu povodní v srpnu 2002 v Praze. Pracovní skupina měla možnost se seznámit s následky přibližně rok po povodních. Článek je rozčleněn do tří částí, které odpovídají třem logickým krokům protipovodňové ochrany:

Před povodní - vypracování dlouhodobé strategie protipovodňové ochrany, morfohydrologické zhodnocení městského areálů, vymezení zátopových oblastí, plánování evakuace, to vše na základě studia historických podkladů a zkušeností, geomorfologického mapování.

Během povodně - hlavním cílem je zajistit bezpečnost obyvatel a snížit na minimum majetkové škody, a zajištění fungující komunikace pro koordinaci činnosti povodňových orgánů, zajištění včasné a přesné informovanosti obyvatelstva.

Po povodni - odstranění následků povodní, poučení z povodní, analýza účinnosti stávajících protipovodňových opatření, př́ípadně jejich úprava, aktualizace povodňových plánů a označení problematických míst a postupů.

Obr. 1 - Morfologie nivy Vltavy v Praze; a (přerušovaná čára) - rozsah nivy, b (čerchovaná čára) - jesepový val, c (vodorovná šrafa) - blízká niva, d (svislá šrafa) - vzdálená niva, e - ochranná hráz, f - vymezemí morfohydrologické jednotky, g - most.

Obr. 2 - Zřícený dům v Karlíně (léto 2002)

Obr. 3 - Členové pracovní skupiny „Povodně“ při práci.

Members of Working Group I: Rafael Baena Escudero is with University of Sevilla, email: baena@us.es. Belén García Martínez is with University of Sevilla, e-mail: mbelen@us.es. Laura Giacomini is with University of Padua, e-mail:

laura.giacomini@unipd.it. Inmaculada Guerrero Amador is with University of Sevilla, e-mail: Inmaguer@us.es. Andrea Guaran is with University of Udine, e-mail: andrea.guaran@dest.uniud.it. Filip Hartvich is with Charles Univesity in Prague, e-mail: hartvich@irsm.cas.cz. Alexandra Králová is with Charles Univesity in Prague, e-mail: AKralova@cpoj.cz. Brigitte Leicht (University of Mainz), e-mail: B.Leicht@geo.uni-mainz.de. Andreas Licht is with University of Mainz, e-mail: Kuehlimainz@gmx.de. Lara Marchiol is with University of Udine, e-mail: blade77@despammed.com. Hannah Neu is with University of Mainz, e-mail: Hannah.neu@web.de. Luca Pezzullo is with University of Padua, e-mail: luca.pezzullo@unipd.it. Veronika Weingerová is with Charles Univesity in Prague. 